\title{
Mitochondrial DNA in bank voles Clethrionomys glareolus in Ireland: evidence for a small founder population and localized founder effects
}

\author{
Anthony RYAN, Eamonn DUKE and James S. FAIRLEY*
}

Ryan A., Duke E. and Fairley J. S. 1996. Mitochondrial DNA in bank voles Clethrionomys glareolus in Ireland: evidence for a small founder population and localized founder effects. Acta Theriologica 41: 45-50.

Bank voles Clethrionomys glareolus Schreber, 1780 were first discovered in Ireland in 1964. They are confined to the south-west and, judging by their rate of spread, are a recent introduction. Mitochondrial DNA was extracted from 81 bank voles from 5 localities. Only 2 haplotypes were observed, indicating that the founder population was small. There were marked differences in the relative frequencies of haplotypes between sites. These are most readily explained by local founder effects brought about by the habitat preference of this rodent and sustained by the territorial behaviour of females.

Department of Zoology, University College, Belfield, Dublin 4, Ireland (AR, ED); Department of Zoology, University College, Galway, Ireland (JSF)

Key words: Clethrionomys glareolus, mitochondrial DNA, founder effect

\section{Introduction}

The bank vole Clethrionomys glareolus Schreber, 1780, has a marked preference for heavy cover (Alibhai and Gipps 1991). In Ireland it was first discovered in 1964 (Claassens and O'Gorman 1965) and its geographical distribution determined in 1970 (Fairley 1971). The most complete recent resurvey was in 1982 by Smal and Fairley (1984), who showed it to be present over some $12500 \mathrm{~km}^{2}$ in the south-west. These authors found that on suitable terrain spread averaged 2-4.5 $\mathrm{km} \times \mathrm{yr}^{-1}$ (though it was much slower in some districts) and concluded from this and the distribution that the animal is a recent introduction to Ireland, having probably been brought in no earlier than 1940 .

Tegelström (1987) has demonstrated that considerable variation exists in the mitochondrial DNA (mtDNA) of $C$. glareolus, recording 55 haplotypes in 85 individuals trapped in Fennoscandia. Byrne et al. (1990) examined the mtDNA of 23 animals from 4 localities in Ireland using the restriction enzyme Hae III and found no variation whatsoever. This suggested that the present population of Irish bank voles is descended from a recent introduction of a small number of individuals.

\footnotetext{
* To whom reprint requests should be sent.
} 
There are documented instances of rodent populations being established from a few individuals, for example the musk rat Ondatra zibethicus in Ireland (Fairley 1982), and population explosions of house mice Mus musculus (Berry 1981).

In order to examine more closely the phenomenon of small founder populations, we have examined the mtDNA of Irish bank voles from a larger sample $(n=81)$ from 5 localities using 3 restriction enzymes: Hinf I, Hae III and Mbo I. As these four-cutter enzymes produce many fragments, they therefore increase the probability of detecting any variation that may be present.

\section{Materials and methods}

Five widely-separated sites were chosen for study: (1) *Ross Island (in fact now a peninsula), Killarney $0.6 \mathrm{~km}^{2}$ (Irish grid reference) V99, (2) Doneraile $1.3 \mathrm{~km}^{2} \mathrm{R} 60$, (3) *Curragh Chase $2.0 \mathrm{~km}^{2}$ R44, (4) Coole Park $1.3 \mathrm{~km}^{2}$ M40 and (5) *Dundrum $0.6 \mathrm{~km}^{2}$ R94. Three sites (marked *) were the same as those used by Byrne et al. (1990). Doneraile is a park with woodland strips and patches of heavy ground cover. All the other locations are heavily wooded. The locations of all sites are shown on Fig. 1.

Animals were trapped in September and October 1993, using Longworth live traps baited with oats, and transferred to wooden holding boxes provided with hay as bedding and oats, apple and water ad libitum. All voles were killed, by decapitation, within $48 \mathrm{hr}$ of capture. Mitochondria were obtained from fresh liver tissue by the method of Lansman et al. (1981) and mtDNA was prepared from the mitochondrial fraction according to the alkaline extraction method of Palva and Palva (1985). Typically about $0.5 \mu \mathrm{g}$ of mtDNA was obtained from a bank vole liver of $1-2 \mathrm{~g}$.

Approximately $200 \mathrm{ng}$ of mtDNA were digested with each restriction enzyme, Hinf I, Hae III and Mbo I, according to the instructions of the manufacturer (Boehringer Mannheim). Electrophoresis was

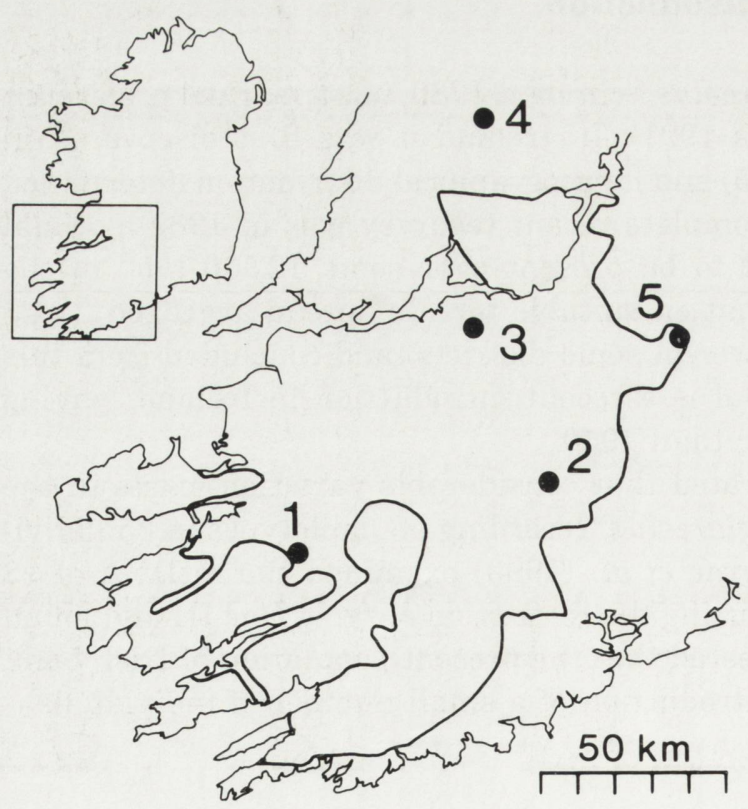

Fig. 1. Map of south-west Ireland showing the locations (dots) where bank voles were trapped: (1) Killarney, (2) Doneraile, (3) Curragh Chase, (4) Coole Park, (5) Dundrum. The bold line indicates the limit if the range of the bank vole in 1982. 
carried out using 5\% polyacrylamide gels. A mixture of Boehringer Mannheim molecular weight markers II and V were included to cover the whole range of fragment sizes produced. Electrophoresis was continued for at least $20 \mathrm{hr}$ until the dye front had reached the end of the gel. Gels were stained by the silver staining method of Guillemette and Lewis (1983), which is highly sensitive and enhances the ready detection of small fragments.

\section{Results}

Two restriction patterns, which are shown in Fig. 2, were found for each enzyme. Fragment sizes are given in Table 1 . In each case the 2 variants was arbitrarily identified as A or B. Patterns for all 3 enzymes were obtained from 72 voles: $45 \mathrm{~A}^{1} \mathrm{~A}^{2} \mathrm{~A}^{3}$ and $27 \mathrm{~B}^{1} \mathrm{~B}^{2} \mathrm{~B}^{3}$, where the superscripts refer to results obtained from (1) Hinf I, (2) Hae III and (3) Mbo I. There were therefore only 2 haplotypes, the sequence divergence between them being $0.410 \%$ (Nei and Li 1979). As the yield of mtDNA is quite low and several samples required redigestion for reliable assignment to a particular restriction pattern, a complete restriction pattern could not be obtained for 9 voles. For these animals the results were as follows: $A^{1}{ }_{-}^{2}{ }^{3}$ (2), $\mathrm{A}^{1} \mathrm{~A}^{2}{ }^{3}{ }^{3}(4), \mathrm{B}^{1-{ }_{-}{ }^{3}}$ (1), $\mathrm{B}^{1} \mathrm{~B}^{2}{ }_{-}^{3}(1),-{ }^{1} \mathrm{~B}^{2} \mathrm{~B}^{3}$ (1). No more than 3 incomplete phenotypes were obtained at any site.

The numbers of haplotypes recorded at each site are given in Table 2. The difference in occurrences of types between sites is highly significant $\left(\chi^{2}=25.079\right.$, $\mathrm{df}=4, p<0.001$ ). A more liberal approach which includes the incomplete data and assumes that no new combinations would appear gives $\chi^{2}=25.860, \mathrm{df}=4$ $p<0.001$.

Fig. 2. Sections of silver stained polyacrylamide gels showing restriction digestion results for: Hinf $I-$ lanes 2 and 3 , Hae III - lanes 5 and 6, and Mbo Ilanes 8 and 9 . The haplotype represented in each case is indicated below the appropriate lane number. Markers (M) are shown in lanes 1, 4 and 7 .

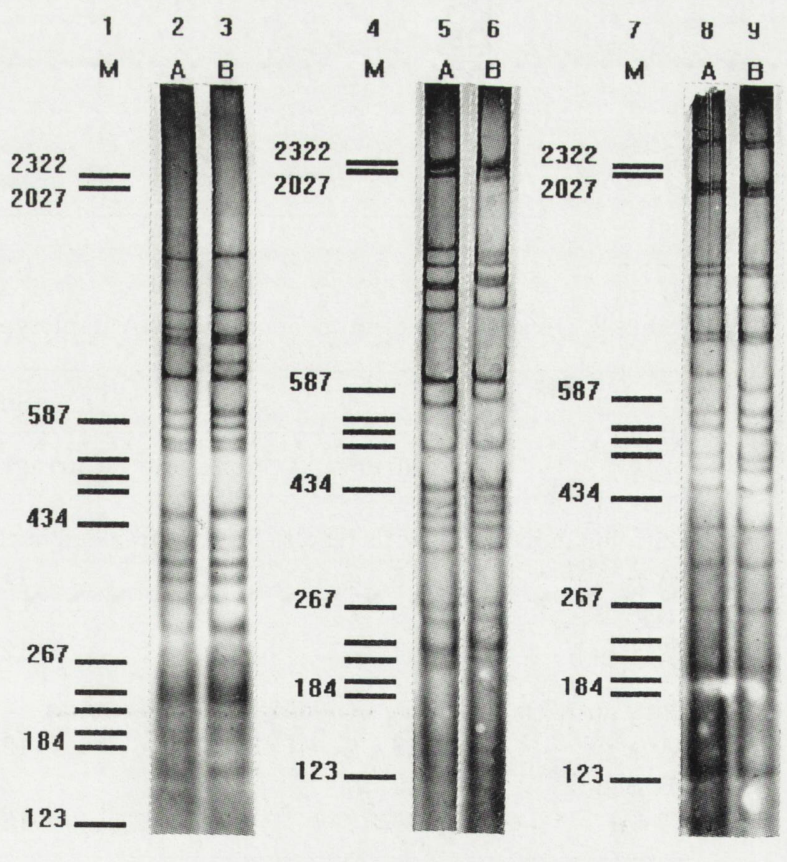


Table 1. Fragment sizes of bank vole mtDNA as determined by electrophoresis after digestion by Hinf I, Hae III and Mbo I. Sizes for all restriction fragments are shown in restriction pattern $\mathrm{A}$ in all cases. For restriction pattern $B$ the bands are the same except where indicated. The absence of a band is shown by "-".

\begin{tabular}{|c|c|c|c|c|c|}
\hline $\operatorname{Hinf}$ I A & $\operatorname{Hinf}$ I B & Hae III A & Hae III B & Mbo I A & $M b o$ I B \\
\hline 1413 & & 1998 & & 2500 & \\
\hline 1093 & & 1943 & & 2024 & \\
\hline 1003 & - & 1837 & & 1956 & \\
\hline 947 & & 1244 & - & 1292 & \\
\hline 921 & & - & 1210 & 1248 & \\
\hline 895 & & 1144 & & 1050 & \\
\hline - & 798 & 1024 & & 915 & \\
\hline 733 & & 995 & & 884 & \\
\hline- & 629 & 890 & & 718 & - \\
\hline 617 & & 592 & & - & 670 \\
\hline 593 & & 542 & & 598 & \\
\hline 571 & & 470 & & 571 & \\
\hline 560 & & 408 & & 510 & \\
\hline 444 & & 387 & & 487 & \\
\hline 403 & & 367 & & 455 & \\
\hline 388 & & 348 & & 397 & \\
\hline 366 & & 324 & & 346 & \\
\hline 345 & & 257 & & 295 & \\
\hline 326 & & 244 & & 235 & \\
\hline 290 & & 223 & & 159 & \\
\hline 234 & & 212 & & 133 & \\
\hline 226 & & 157 & & & \\
\hline 217 & & 148 & & & \\
\hline 209 & & 141 & & & \\
\hline 201 & & & & & \\
\hline 175 & & & & & \\
\hline
\end{tabular}

Table 2. Occurrences of mitochondrial DNA haplotypes at the sites sampled in Ireland.

\begin{tabular}{|c|c|c|c|c|c|}
\hline \multirow{2}{*}{ Haplotype } & \multicolumn{5}{|c|}{ Site } \\
\hline & Killarney & Doneraile & Curragh Chase & Coole Park & Dundrum \\
\hline
\end{tabular}

Data for individuals with results for all three enzymes

$\begin{array}{lrrrrr}\mathrm{A}^{1} \mathrm{~A}^{2} \mathrm{~A}^{3} & 5 & 8 & 11 & 5 & 16 \\ \mathrm{~B}^{1} \mathrm{~B}^{2} \mathrm{~B}^{3} & 9 & 6 & 1 & 11 & 0 \\ \text { Total } & 14 & 14 & 12 & 16 & 16\end{array}$

Data for all individuals, including incomplete data

$\begin{array}{lrrrrr}\mathrm{A}^{1} \mathrm{~A}^{2} \mathrm{~A}^{3} & 6 & 9 & 13 & 5 & 18 \\ \mathrm{~B}^{1} \mathrm{~B}^{2} \mathrm{~B}^{3} & 10 & 7 & 2 & 11 & 0 \\ \text { Total } & 16 & 16 & 15 & 16 & 18\end{array}$




\section{Discussion}

The very low level of variation recorded in the mtDNA of Irish bank voles here reinforces the view that the founding population was small, the minimum number of foundresses being 2. Although, of course, it is also entirely possible that the founding population showed little variability, the only data from outside Ireland are that of Tegelström (1987). Byrne et al. (1990) reported a single phenotype only for Hae III. This is explained as the difference between our two phenotypes is a small change in mobility of one band.

Fennoscandian bank voles are known to be variable in their mtDNA (Tegelström 1987). Unfortunately, comparison of results is difficult. Only 1 enzyme was common to both studies (Hae III). Moreover, Tegelström used 5 restriction enzymes and sampled far fewer animals at each location - a total of 85 voles from 25 sites. Moreover we were investigating the extent of mtDNA variation in Irish bank voles in general, whereas the Fennoscandian study examined the extent of transfer of mtDNA from 1 species to another. Regardless of the relative sizes of Fennoscandia and south-west Ireland, it would seem reasonable to expect higher variability in the Irish voles if the Irish population was representative of some putative ancestral European population, rather than a small founding group.

There were marked differences in the relative frequencies of types between sites, with a marked preponderance of $\mathrm{A}^{1} \mathrm{~A}^{2} \mathrm{~A}^{3}$ at Curragh Chase and no instances of $\mathrm{B}^{1} \mathrm{~B}^{2} \mathrm{~B}^{3}$ at Dundrum whatsoever. While Dundrum was at the limit of the bank vole's range in 1982 (Smal and Fairley 1984) and the absence of type $\mathrm{B}^{1} \mathrm{~B}^{2} \mathrm{~B}^{3}$ might be explained by a further founder effect, Curragh Chase is towards the centre of the range, close to the surmised point of original introduction of the vole (Fairley 1984, Smal and Fairley 1984).

It might be argued that the scarcity of $\mathrm{B}^{1} \mathrm{~B}^{2} \mathrm{~B}^{3}$ at Curragh Chase and its absence at Dundrum was because trapping was restricted to a small area and that therefore closely related animals were being sampled. This is unlikely, particularly at Dundrum. At Curragh Chase the voles were trapped on either side of $1.3 \mathrm{~km}$ of road and at Dundrum close to forest roads which formed the sides of a rough triangle $0.6 \times 0.9 \times 1.0 \mathrm{~km}$.

The best explanation for these distributions is in a local founder effect. Most terrain in Ireland is unsuitable for bank voles because of their preference for heavy cover. They are mainly limited to woodland, scrub and ground that is uncultivated for a time, where thick ground vegetation can develop. Over cultivated ground most movement is probably along hedges. Indeed spread has been slow in districts with large fields and thin hedges (Smal and Fairley 1984). Initial colonisation of several of the sites investigated here, all large "islands" of suitable habitat for C. glareolus, may therefore have been by a few individuals arriving via a hedge, thus increasing the probability of a founder effect in the mtDNA.

The territorial behaviour of bank voles is complex (Flowerdew et al. 1985). However, it is clear that females are territorial at least in the breeding season (Alibhai and Gipps 1991, Flowerdew 1993). It is therefore likely that, once a 
population of bank voles becomes established in a large patch of favourable habitat, the introduction of unrelated female bank voles, and therefore new mtDNA types, via the original routes is inhibited.

Acknowledgements: We are indebted to the Office of Public Works and to Coillte Teoranta for permission to trap bank voles in their properties.

\section{References}

Alibhai S. K. and Gipps J. H. W. 1991. Bank vole. [In: The handbook of British mammals. G. B. Corbet and S. Harris, eds, 3rd edition]. Blackwell, Oxford: 192-203.

Berry R. J. 1981. Town mouse, country mouse: adaptation and adaptability in Mus musculus (Mus musculus domesticus). Mammal Review 11: 91-136.

Byrne J. M., Duke E. J. and Fairley J. S. 1990. Some mitochondrial DNA polymorphisms in Irish wood mice (Apodemus sylvaticus) and bank voles (Clethrionomys glareolus). Journal of Zoology, London 221: 299-302.

Claassens A. M. J. and O'Gorman F. 1965. The bank vole Clethrionomys glareolus Schreber a mammal new to Ireland. Nature, London 205: 923-924.

Fairley J. S. 1971. The present distribution of the bank vole Clethrionomys glareolus Schreber in Ireland. Proceedings of the Royal Irish Academy 71B: 183-189.

Fairley J. S. 1982. The muskrat in Ireland. Irish Naturalists' Journal 20: 405-411.

Fairley J. S. 1984. An Irish Beast Book. 2nd edition. Blackstaff Press, Belfast: 1-334.

Flowerdew J. 1993. Mice and voles. Whittet Books, London: 1-128.

Flowerdew J. R., Gurnell J. and Gipps J. H. W. (eds) 1985. The ecology of woodland rodents bank voles and field mice. Symposia of the Zoological Society of London 55: 1-418.

Guillemette J. G and Lewis P. N. L. 1983. Detection of sub-nanogram quantities of DNA or RNA on native and denaturing polyacrylamide and agarose gels by silver staining. Electrophoresis 4: 92-94.

Lansman R. A., Shade R. O., Shapira J. F. and Avise J. C. 1981. The use of restriction endonucleases to measure mitochondrial DNA sequence relatedness in natural populations. III Techniques and potential applications. Journal of Molecular Evolution 17: 214-226.

Nei M. and Li W. 1979. Mathematical model for studying genetic variation in terms of restriction endonucleases. Genetics 76: 5269-5273.

Palva T. K. and Palva E. T. 1985. Rapid isolation of animal mitochondrial DNA by alkaline extraction. FEBS Letters 192: 267-270.

Smal C. M. and Fairley J. S. 1984. The spread of the bank vole Clethrionomys glareolus in Ireland. Mammal Review 14: 71-78.

Tegelström H. 1987. Transfer of mitochondrial DNA from the northern red-backed vole (Clethrionomys rutilus) to the bank vole (C. glareolus). Journal of Molecular Evolution 24: 218-227.

Received 9 May 1995, accepted 30 January 1996. 